\title{
СУЧАСНИЙ СТАН НАУКОВО ОБГРУНТОВАНОЇ СТОМАТОЛОГІЧНОЇ ПРАКТИКИ
}

\author{
П. А. Гасюк, Н. О. Гевкалюк, В. В. Щерба, С. М. Придруга \\ ДВНЗ “Тернопільський держсавний медичний університет імені І. Я. Горбачевського”
}

\section{THE CURRENT STAGE OF SCIETIFICALLY SUBSTANTIATED DENTAL PRACTICE}

\author{
P. A. Hasiuk, N. O. Hevkaliuk, V. V. Shcherba, S. M. Prydruha \\ SHEI "Ternopil State Medical University by I. Ya. Horbachevsky"
}

У статті розглянуті основні наукові принципи, питання та проблеми науково обгрунтованої стоматологічної практики.

The article adduces the basic scientific principles, issues and problems of scientifically substantiated dental practice.

Вступ. Кожен представник медичної професії напевно хоча б раз в житті замислювався, в чому суть лікарського мистецтва. Традиційна відповідь на це питання приблизно така: “Лікарське мистецтво складається з об'єму знань, необхідних для розуміння причин і патофізіологічних механізмів захворювань, 3 клінічного досвіду, інтуїції і набору якостей, які в сукупності складають так зване “клінічне мислення”.

Основна частина. Культивоване в рамках традиційної медичної освіти поняття “клінічне мислення" не означає чіткої і цілісної концепції лікування і засновано на аналогіях, переважно у вигляді клінічних ситуацій з життя великих лікарів і повчань брати приклад із старших колег по роботі [2]. На рубежі 80-90-х років у медицині англомовних країн сформувалася нова галузь знань - клінічна епідеміологія. Найбільшу популярність здобули роботи групи канадських вчених, які вперше спробували розглянути лікарське мистецтво 3 погляду суворих наукових принципів. Ці наукові постулати надали і роблять величезний вплив на стиль і стоматологічної практики, а також світогляд лікарів на Заході [4]. На жаль, до недавнього часу переважна більшість вітчизняних лікарів абсолютно не були знайомі з новою концепцією.

Завданням клінічної епідеміології є розробка наукових основ стоматологічної практики - зведене правило для ухвалення клінічних рішень. Головний постулат клінічної епідеміології такий: кожне клінічне рішення повинне базуватися на суворо доведених наукових фактах. Цей постулат отримав назву
"Evidence-based medicine", в буквальному перекладі - “медицина, заснована на фактах" або, що точніше відображає значення терміна, “науково обгрунтована медична практика”, або “науково-доказова медицина".

У пошуках відповіді на клінічну проблему лікарстоматолог може користуватися різними джерелами інформації і отримувати різноманітні, інколи взаємовиключаючі факти і рекомендації [5]. Тому інший найважливіший принцип науково обгрунтованої стоматологічної практики пов’ язаний з критичним аналізом інформації: “вага” кожного факту тим більша, чим адекватніша наукова методика дослідження, в ході якої факт отриманий.

Загальновідомо, що тільки експеримент може показати, що є в науці істиною. Чим ретельніше він поставлений, тим вища вірогідність того, що його результати обумовлені реально існуючим зв' язком між явищами, а не артефактом і не випадковим збігом обставин. Відтворюваність - одна $з$ найважливіших умов об'єктивності даних. “Золотим стандартом” вважаються рандомізовані контрольовані дослідження. Індивідуальний лікарський досвід і думка експертів або “авторитетів" розглядаються, якщо не мають достатньої наукової основи [1].

На відміну від фундаментальних медико-біологічних наук, клінічну стоматологію цікавлять питання, відповіді на які можуть дати дослідження тільки на живих людях, а не на експериментальних тваринах, культурах тканин або клітинних мембранах. Клінічне дослідження важко віднести до “чистого експеримен-

(ㄱ П. А. Гасюк, Н. О. Гевкалюк, В. В. Щерба, С. М. Придруга 
ту”. Насправді, тут об'єкт вивчення - пацієнт, який вправі сам визначати свої вчинки, а експериментатор-лікар з особистим професійним досвідом, схильностями і часом помилковими думками.

Ось чому в клінічних дослідженнях завжди закладена небезпека систематичних помилок - упередженості, уникнути яких можна лише слідуючи чітким науковим принципам. Якнайповнішою мірою таким принципам відповідають рандомізовані контрольовані клінічні дослідження. Вони обов' язково припускають наявність дослідної і контрольної груп, пацієнтів розподіляють по групах методом випадкової вибірки (рандомізація), стежачи при цьому, щоб групи не розрізнялися за параметрами, що впливають на результат стоматологічного дослідження.

При проведенні дослідження лікарем-стоматологом часто пацієнт не знає, отримує він плацебо чи ліки (подвійний сліпий метод). Всі пацієнти простежуються протягом визначеного, часто доволі тривалого відрізку часу (проспективне дослідження), після закінчення якого порівнюється частота настання клінічно важливого кінцевого результату (одужання чи ускладнення) в дослідній і контрольній групах. Нерідко для проведення подібних досліджень залучаються тисячі і десятки тисяч стоматологічних хворих в різних наукових центрах і країнах.

Відповідно до сучасних західних стандартів жоден новий метод лікування, профілактики або діагностики не може бути визнаний без обов' язкової ретельної перевірки в ході рандомізованих контрольованих досліджень. Такий підхід дещо відрізняється від української практики.

В чому причина вкрай низького “імунітету” в українських медиків до сумнівних методів діагностики і лікування? Очевидно, у відсутності культури критичної оцінки наукових публікацій і незнанні принципів науково обгрунтованої медичної практики.

Останнім часом активно заговорили про науково обгрунтовану медичну практику як про новий світогляд в медицині. Щорічно публікуються результати сотень рандомізованих контрольованих досліджень, які змінюють загальноприйняті стандарти лікування. Разом $з$ тим, встановлено зворотну залежність між ступенем інформованості лікаря-стоматолога про сучасні методи лікування та часом від моменту закінчення медичного вузу. Зрозуміло, що грамотний лікар прагне бути в курсі останніх досягнень медицини, і відповіді на питання, що виникають біля стоматологічного крісла, потрібно шукати в стоматологічній літературі [3].

Новими є науково обгрунтовані підходи до пошуку джерел інформації і її критичного осмислення. По мірі все більш широкого розповсюдження нових інформаційних технологій (електронні бази даних і журнали, мультимедійні навчальні програми на компактних оптичних дисках і в Інтернеті) розширюються можливості лікарів отримувати найоперативнішу інформацію. 3'явилася необхідність осмислити можливості цих технологій, визначити їх місце, роль і зв'язок 3 традиційними друкарськими виданнями [6]. Науково обгрунтована стоматологічна практика, клінічна епідеміологія навчають стоматолога мистецтва критичного аналізу інформації і уміння співвіднести результати дослідження з конкретною клінічною ситуацією.

Так, чимало провідних медичних університетів Польщі прийшли до усвідомлення, що клінічна епідеміологія повинна бути введена в обов' язковий курс як одна $з$ фундаментальних дисциплін. Вважають, що саме недооцінка ролі клінічної епідеміології та науково обгрунтованої лікарської практики - одна 3 найбільш серйозних перешкод на шляху реформування польської медицини, чи не важливіша, ніж брак грошей та застаріле устаткування. 3 цим твердженням важко не погодитися. Замість того, щоб механічно запозичувати або копіювати зовнішні прояви технічного прогресу, необхідно створити систему, яка б автоматично відтворювала ці досягнення.

Висновки. Для сучасного лікаря-стоматолога навички критичної оцінки конкретної клінічної ситуації такі ж важливі і необхідні, як, наприклад, уміння провести огляд стоматологічного хворого. Науково обгрунтована стоматологічна практика в ідеологічному сенсі - це спроба лібералізувати систему авторитарних відносин, що склалася протягом століть у стоматології, ставлячи в центр ухвалення рішень не укорінену традицію, а лікаря - відповідального і компетентного, інформованого і критично мислячого.

\section{Лiтература}

1. Андреев А. А. Педагогика высшей школы (Прикладная педагогика) : учебное пособие / А. А. Андреев. - М. : МЭСИ, 2000.-Кн. 1. -141 с.

2. Жуков Г. Н. Основы общей профессиональной педа-

гогики : учебное пособие / Г. Н. Жуков, П. Г. Матросов, С. Л. Каплан ; под общ. ред. проф. Г. П. Скамницкой. - М. : Гардарики, 2005.-382 с.

3. Косенко К. М. Методичні аспекти формування у сту- 
дента-стоматолога практичних навичок та умінь / К. М. Косенко // Вісник стоматології. - 2006. - № 3. - С. 89-90.

4. Образцов П. И. Информационно-технологическое обеспечение учебного процесса в вузе / П. И. Образцов // Высшее образование в России. - 2001. - № 6. - С. 46-50.

5. Педагогика : учебник / [Л. Крившенко и др.]; под ред.
Л. Крившенко. - М., 2005. Применение инновационных технологий как средство активизации обучения студентов в вузе. -URL: www.bahkrabot.com/work/work 63711html.

6. Прокофьева Т. Ю. Становление и развитие дистанционного обучения в мире [Електронний ресурс]. - Режим доступу: http://www.samoupravlenie.ru/29-09.php. 